\title{
Difficulties in Translating Items Description from Tugu Pahlawan Museum Surabaya, Indonesia
}

\author{
Kathleen Liuray* \\ Graduate Program, Faculty of Letters, Petra Christian University, Jl. Siwalankerto 121-131, \\ Surabaya 60236, Indonesia
}

\begin{abstract}
This paper focuses on the difficulties that are found while translating items description that are displayed in one of the museums in Surabaya, Indonesia which is the Tugu Pahlawan Museum. There are three difficulties that will be discussed in the end of the paper, which is having knowledge of the subject that is going to be translated, the tendency to copy the original translated texts, and abbreviations or terms that cannot be found in the Internet. There will be five tables to show the progress and the differences between the original translated texts and the revised texts.
\end{abstract}

Keywords: Knowledge, local abbreviation, original translation, revised text

\section{Introduction}

Translation is something easy to say but hard to do. A lot of people think that if someone can speak another language or is learning a second language, need to be able translate everything. And it is something that is still believed by thousands of people, while the truth is very different. To be good translator needs to master the second or third language learning because if someone does not master the language, it will be very hard to look for the choices of words that are needed in translation. Translators also need to always develop their skill and always keep connected to at least two different cultures [1]. Cultural knowledges are also an important thing, because a translator needs to know what the dos and the don'ts in a certaine country or language. A translator also has to keep practicing, in order to be able to choose the correct term and words when they are translating.

One of the translation class assignments was to go to Tugu Pahlawan Museum that is located in Surabaya, East Java, Indonesia. Alongside with the classmates went there and took pictures of every signboard that was placed in front of the items and have to revise the incorrect ones. The researcher found quite a lot of signboards, so it is decided to divide them for five people. It is divided into three parts, the front hall of the museum, the first floor, and the second floor. From the total of 148 pictures that took from the museum a primary data, and got to translate 27 of the pictures.

Because of the popular positive opinions about translation, a lot of people still believed that translation is an easy task that every person can do, as long as they are able to speak and understand the language they are about to translate [2]. However, based on

* Corresponding author: kathleenliuray@gmail.com 
Comben's article, a translator should have seven things before visitor able to be a good translator, and one of the important things is reading and comprehension skills, which means the researcher needs to understand the culture or background of the source text so that the translation will be a very precise one [1]. This research project will be able to prove that translation is a difficult thing to do that needs a good preparation, a very good understanding about the subject that are going to be translated and have to be done carefully. This research project will also be able to show that there are several difficulties that a translator will have to overcome in order to finish a task. In this research project, there are two major things that the researcher would like to explore, which are: first, what are the things that a translator needs to focus on when the researcher is translating historical events? Second, how a translator can get the knowledge of the subject to translate.

\section{Purpose of the study}

The intention of this research project is to know and understand the hardships that every translator will have to overcome when they are translating texts. This research project is focusing on the challenges and difficulties and come through when the researcher was translating the explanation from the Tugu Pahlawan Museum, from the source text which is in Indonesian, to the target text which is in English. The problems that were found in this research project were not only been experienced by the writer but also the whole group of the translation team, where it shows that the hardships that are found are not only applicable to one person, but to every translator.

Research Fengling [3] the conceptual model this research project is using Nida's translation process (Figure 1), where the source text or language is being analyzed, so that the translator can understand fully about the background, the culture, the context of the source text or language. After being analyzed, the source text or language will be transferred to the receptor's text or language, with the source text or language being restructured to the receptor's language and text. The source text or language needs to be restructured in order to make the source text or language makes sense in the receptor's text or language.

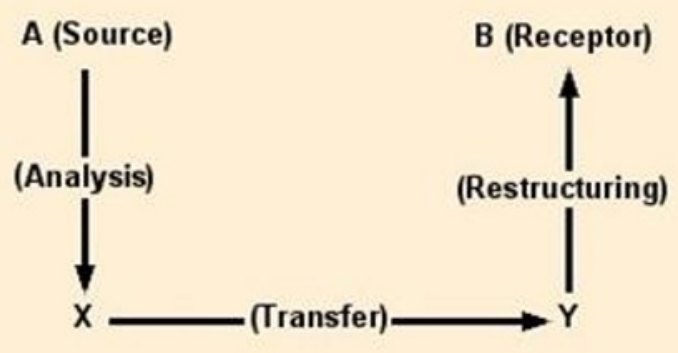

Fig. 1. Translation process

\section{Research methods}

The first thing that are done in this research project is to go to the Tugu Pahlawan Museum (Heroes Monument and $10^{\text {th }}$ November Museum) that is located in Pahlawan Street, Surabaya. And the next thing that needs to be done is taking pictures of the explanations of the items and events throughout the museum. Since the museum is a two-story museum, the translator team decided to separate the photos into five groups; the front hall, the left side of the first floor, the right side of the first floor, the front part of the second floor, and the back 
part of the second floor. There are two types of original text, the first one is in Indonesian and the second one the one that had been translated to English by the museum's translator [4]. Museums have been used by tourists, so international languages are needed [5]. After the translation team are done with collecting the data that are needed to be translated, then it is gathered as many information as possible from the internet; mainly from Google and Wikipedia, in order to be able to use the proper terms when translating.

When the translator team had gathered the information that happened in the past, there are several terms that can be used for certain words, for example "Pejuang Arek-Arek Suroboyo", and deciding whether to use the original translated version or using another version that are found in Wikipedia. Gathered information about the weapons that were used in the past, whether the term that were already translated in the original version is already the correct term or not. The last thing that the translator team do was comparing and choosing the revised translation version, since there are five different version that each member of the team did [6]. Different terms for some Indonesian words that could not be found in the internet, so we had to decide which term fits the best for the sentence.

\section{Process and difficulties in translating}

The first table here is taken from the front hall of the museum. In this part, no have any troubles understanding the original Indonesian texts.

Table 1. Translation front hall of the museum.

\begin{tabular}{|c|c|c|c|c|}
\hline No. & Original Indonesian & Revised Indonesian & $\begin{array}{c}\text { Original } \\
\text { Translation }\end{array}$ & Revised Translation \\
\hline A1 & $\begin{array}{l}\text { Suasana di Jalan } \\
\text { Tunjungan tempo dulu. }\end{array}$ & & $\begin{array}{l}\text { The situation of } \\
\text { Tunjungan Street in } \\
\text { the past. }\end{array}$ & $\begin{array}{l}\text { Tunjungan Street in the } \\
\text { past. }\end{array}$ \\
\hline A2 & $\begin{array}{l}\text { Gedung Balai } \\
\text { Pemuda (Societet } \\
\text { Simpang) } \\
\text { Gedung yang } \\
\text { bertempat di jalan } \\
\text { Pemuda ini, dahulu } \\
\text { sebagai tempat } \\
\text { berkumpulnya orang- } \\
\text { orang Belanda untuk } \\
\text { berpesta. Tempat ini } \\
\text { juga disebut sebagai } \\
\text { Simpangche club. } \\
\text { Orang-orang pribumi } \\
\text { tidak boleh masuk } \\
\text { kedalam gedung } \\
\text { tersebut. }\end{array}$ & $\begin{array}{l}\text { Gedung Balai Pemuda } \\
\text { (Societet Simpang) } \\
\text { Gedung yang bertempat } \\
\text { di jalan Pemuda dan } \\
\text { dulu disebut sebagai } \\
\text { Simpangche club, } \\
\text { digunakan oleh orang- } \\
\text { orang Belanda untuk } \\
\text { berkumpul dan berpesta. } \\
\text { Orang-orang pribumi } \\
\text { tidak diperbolehkan } \\
\text { memasuki gedung } \\
\text { tersebut. }\end{array}$ & $\begin{array}{l}\text { Balai Pemuda } \\
\text { Building (Societet } \\
\text { Simpang) } \\
\text { The building is } \\
\text { located at Pemuda } \\
\text { street, it used to use } \\
\text { as a place for } \\
\text { gathering Dutch } \\
\text { people to make a } \\
\text { party. The building i } \\
\text { also called as } \\
\text { Simpangche club. } \\
\text { The Indigene (native } \\
\text { people of Indonesia } \\
\text { were not allowed to } \\
\text { come inside the } \\
\text { building. }\end{array}$ & $\begin{array}{l}\text { Balai Pemuda (Societet } \\
\text { Simpang) } \\
\text { This building, which } \\
\text { was also called } \\
\text { Simpangche club, is } \\
\text { located at Pemuda Street } \\
\text { and used to be the place } \\
\text { for the Dutch to gather } \\
\text { and to hold parties. The } \\
\text { indigenous people of } \\
\text { Indonesia were not } \\
\text { allowed to enter the }\end{array}$ \\
\hline
\end{tabular}

However, decided to reconstruct the Indonesian text in order to make the translation process easier. For the revised English text searched Google and Wikipedia to understand better what is the different of indigene and native, which found they are actually different. Native people of a certain country mean that visitor had born and live in that country, but it does not mean that visitor ancestor is from that country. While indigenous people of a certain country mean that their ancestors are originally from that place. That is why decided to use indigene rather than native, and it also makes the description a lot more formal and easier to understand by the foreigners [7]. Revised several grammatical errors that the 
original translation had, like the uses of capital letters and vocabularies that were not correct.

Table 2. Translation front Radio Bung Tomo

\begin{tabular}{|c|c|c|c|c|}
\hline No. & Original Indonesian & $\begin{array}{c}\text { Revised } \\
\text { Indonesian }\end{array}$ & Original Translation & Revised Translation \\
\hline B1 & $\begin{array}{l}\text { Radio Bung Tomo } \\
\text { Radio ini pernah digunakan } \\
\text { oleh masyarakat Tanah } \\
\text { Abang - Jakarta, untuk } \\
\text { mendengarkan pidato-pidato } \\
\text { Bung Tomo. Dan } \\
\text { selanjutnya, pemilik radio } \\
\text { tersebut, Bapak Achmad } \\
\text { menyerahkan kepada Bung } \\
\text { Tomo sebagai apresiasi dan } \\
\text { kenang-kenangan. } \\
\text { Hibah dari: Ny. Soelistomo }\end{array}$ & & $\begin{array}{l}\text { Bung Tomo's Radio } \\
\text { This Radio ever used by } \\
\text { the people of Tanah } \\
\text { Abang Jakarta, to hear } \\
\text { Bung Tomo's Orations. } \\
\text { An than, the Radio's } \\
\text { owner gived to Bung } \\
\text { Tomo as apressiated and } \\
\text { memoried. } \\
\text { Given by: Mrs. } \\
\text { Soelistomo }\end{array}$ & $\begin{array}{l}\text { Bung Tomo's Radio } \\
\text { This radio was used by } \\
\text { the people of Tanah } \\
\text { Abang, Jakarta, to listen } \\
\text { to Bung Tomo's } \\
\text { speeches. And then, Mr. } \\
\text { Achmad, the owner of } \\
\text { the radio, gave it to Bung } \\
\text { Tomo as a token of } \\
\text { appreciation. } \\
\text { Granted by: Mrs. } \\
\text { Soelistomo }\end{array}$ \\
\hline
\end{tabular}

The second table is taken from the first floor of the museum. There are several original Indonesian texts that was revised, because of the inconsistency of the capital letters, punctuations, prepositions and also simplifying the long sentences into a shorter one so that it will be easier to understand and to be translated. In B1, at first, the researher used the word 'donated by' for the English term of 'hibah dari'. However, after my classmates and author met and discuss this, then decided to use 'granted by' because it is more appropriate to use granted rather than donated.

Table 3. Translation front first floor of the museum B2, B3, B7

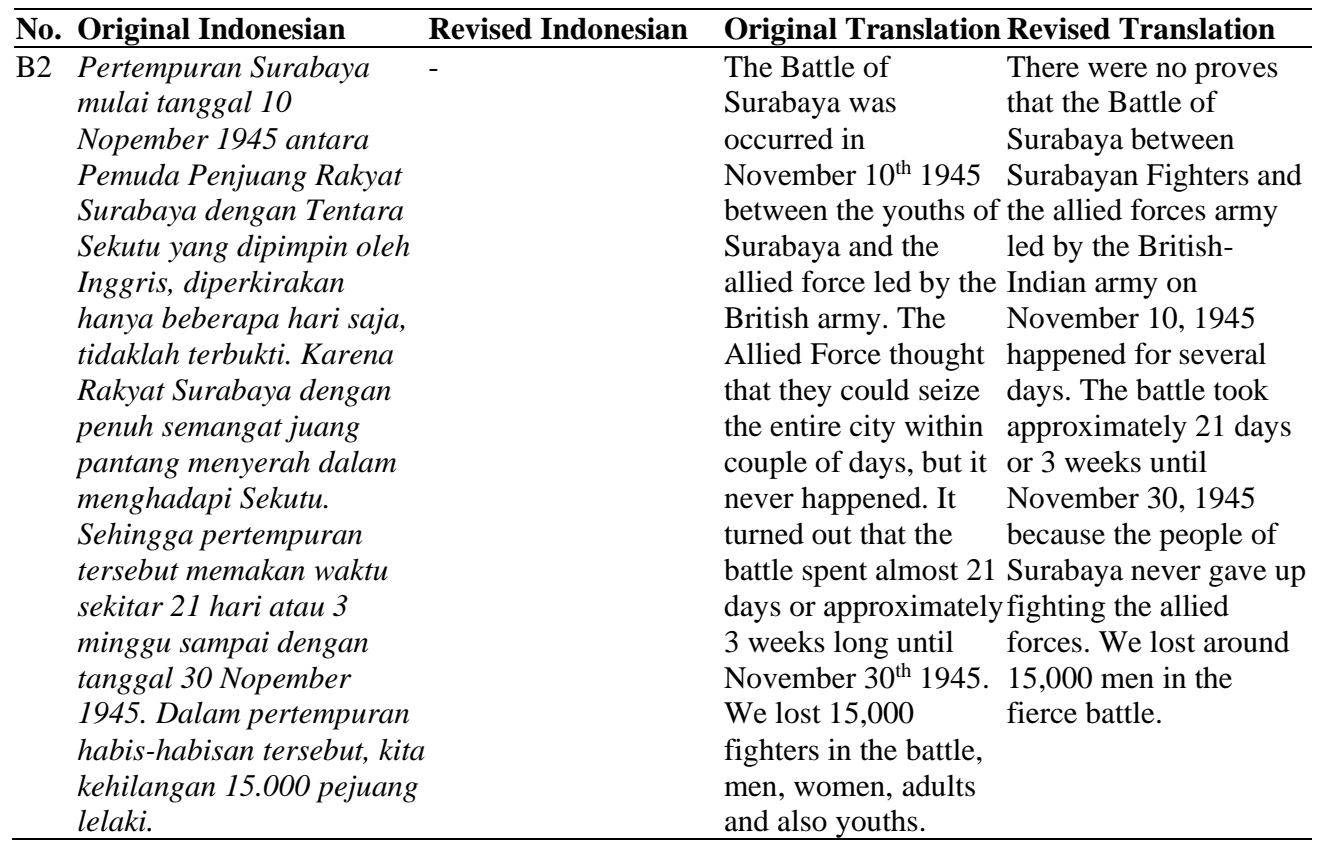

Table 3. continue to the next page 
Table 3. Continue

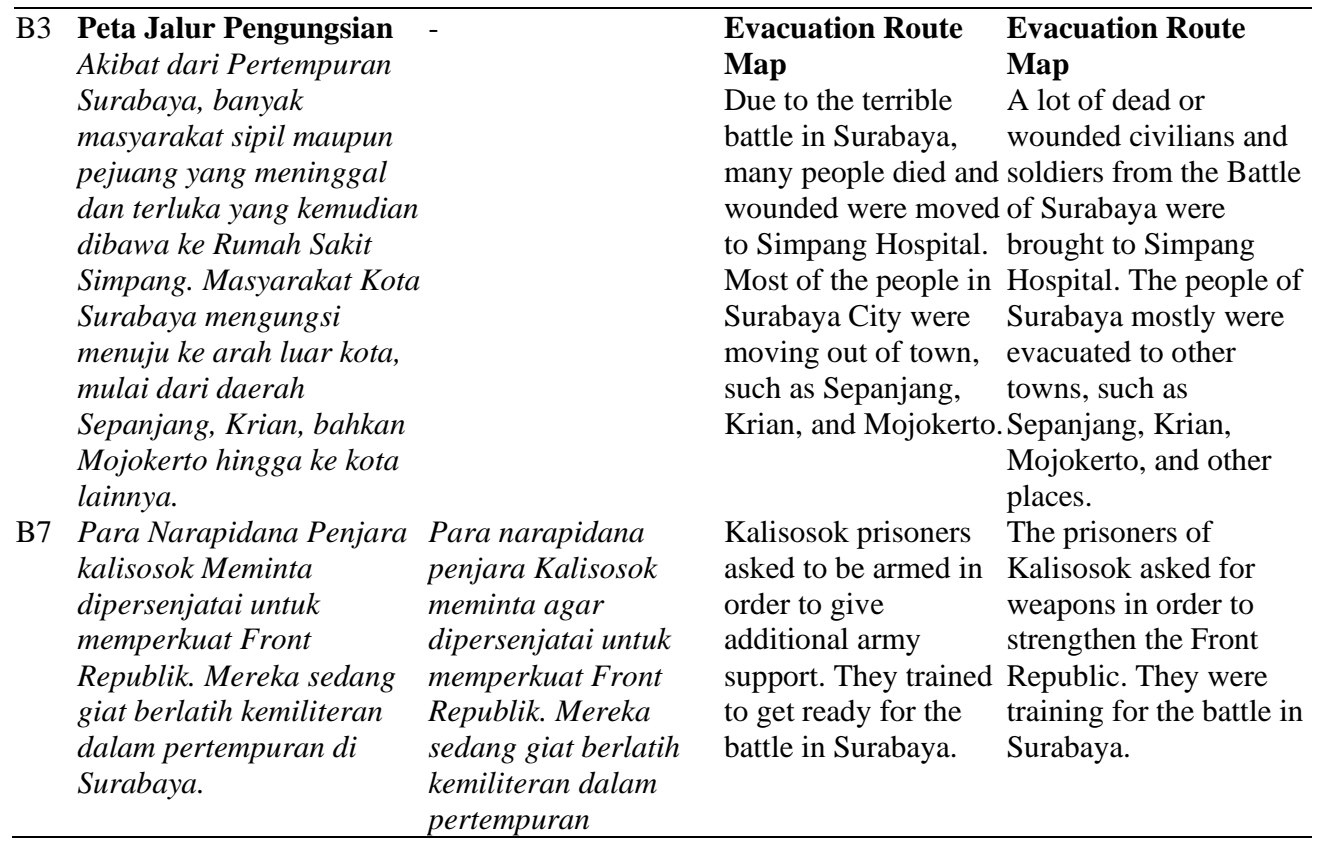

All of the items in the museums are given from the people that are related to the event, and they are granting those items to the museum so that they can put it in the display. In this table, author also revised the incorrect grammars that are used in the original translated text. There are quite a lot of grammatical errors that are found in eight of the pictures. One of them does not have a translated version, so author had to create one by myself, based on the original Indonesian text. Here, author choose the word 'British-Indian Army' instead of 'British Army', because based on the research that my classmate had, there is a special term for the British army that was sent to Surabaya, and it was called as 'British-Indian Army'. The same goes to the 'Imperial Japanese Army', it is a special term that was used for the Japanese Army that was sent to Indonesia in 1945 [8, 9]. Author also use 'Public Security Bureau' (PSB) as the translated term of 'Tentara Badan Keamanan Rakyat', because it is the official English term for BKR. At first, author decided not to change the Indonesian term so that the foreigners will easier to understand. But it turns out that there is an official term for 'Tentara Badan Keamanan Rakyat', so in the end decided to use the official term. The texts that are written in the table above is also from the first floor of the museum. There were a lot of grammatical errors that need to be revised, including the punctuation, the usage of period and comma in numbers, and capitalization of places and names of streets. There were several Indonesian texts that have to be revised, because the original texts are too confusing and hard to understand. Also, the usage of the word 'Surabayan Fighters' for the translated version of 'Pejuang Arek-Arek Suroboyo'. author tried to look for the correct and right term for this, however author could not find it. Author finally decided to use it after the meeting with my classmates, where we agree to use 'Surabayan Fighters' instead of soldiers or even keeping the original term.

Based on the pictures that had been taken from the museum, there are three difficulties that are found while translating the pictures. First of all, is that the translation team had no background or knowledge of Surabayan history [10], where most of the items are related to the history of Surabaya. Having some background or knowledge before translating is very useful, since it can help the translator to easily choose the correct and proper term. The translation team need the help of Google and Wikipedia to know and understand the terms 
and had small researches regarding the items and events that are needed to be translated. The second difficulty is that the translator has the tendency to copy the original translation text [11], because it is located right next to the revised translation column [3]. It will be much easier if there is only the original Indonesian text, so that the translator will not use the same ter $m$ that the original translated version had used. The last difficulty that is found in this research project is that there are a lot of abbreviations and terms that cannot be found in the Internet, since they are terms that were specially used in Surabaya and Indonesia. The translator had to create new terms for it, because the words did not exist before the translation.

\section{Conclusion}

Based on these five tables, there are some difficulties that found while translating these pictures. First of all is that the researcher have no background or knowledge of Surabayan history, where most of the items are related to history of Surabaya. Having some background or knowledge before translating is very useful, since it can help the translator to easily choose the correct and proper term. Since author have minimum knowledge of it, it took to translate these pictures. Author had to look the terms in Google and Wikipedia, and even have a small research regarding the items and events that author had to translate. The second difficulty is that author have the tendency to copy the original translation text, because it was located right next to the revised translation column. If only read the Indonesian and then translate it directly to the revised version, it is much easier, and author don't use the same terms or vocabulary that the original English text used. The last difficulty that author found while translating this assignment is that there were a lot of abbreviations and terms that cannot be found in the Internet, since it is a term that was specially used in Surabaya and Indonesia. Author had to create a new term for it, for example 'Surabayan Fighters'. This term is only used in the translation, while it did not exist before the translation.

\section{References}

1. C. Comben, 7 Important skills every translator should have. Retrieved from: https://www.daytranslations.com/blog/2016/12 /7-important-skills-every-translator8128/ (2016).

2. O. Hadithya, Vivid Journal, 3,2:1-15(2014). http://jurnalvivid.fib.unand.ac.id/index.php/vivid/article/view/15

3. L. Fengling, International Journal of Liberal Arts and Social Science, 5,8,3139(2017). https://www.ijlass.org/data/frontImages/gallery/Vol. 5_No._8/4.31-39.pdf

4. L. Molina, A.A. Hurtado, Meta: Translators' Journal, 47:498-512(2002). https://www.erudit.org/en/journals/meta/2002-v47-n4-meta688/008033ar/abstract/

5. Y. Zhang, Lv. Zitu, C. Feng, Theory and Practice in Language Studies, 3,1:7781(2013). http://www.academypublication.com/issues/past/tpls/vol03/01/11.pdf

6. Z. Seifoori, J. Fattahi, Procedia - Social and Behavioral Sciences,98, 16981705(2014). https://doi.org/10.1016/j.sbspro.2014.03.596

7. K. Rothermich, H.L. Harris, K. Sewell, S.C. Bobb, Speech Communication 112:2229(2019). https://doi.org/10.1016/j.specom.2019.07.002

8. D. Indriasto, A. Solicitor, CREATEVITAS, 3,2:297-308(2014). [in Bahasa Indonesia]. http://eprints.upnjatim.ac.id/7075/1/Doni_Indriasto.pdf

9. M.S. Anwar, S.B. Astuti, Atavisme 20,2:181-196 (2017).

http://doi.org/10.24257/atavisme.v20i2.383.181-196 
10. P.P.J. Maulana, M. Bahruddin, T.H. Dewanto, Jurnal Desain Komunikasi Visual, 2,1:1-9(2014). [in Bahasa Indonesia].

https://jurnal.dinamika.ac.id/index.php/ArtNouveau/article/download/381/204

11. B. Saule, N. Aisulu, Procedia - Social and Behavioral Sciences,136:119-123(2014). https://doi.org/10.1016/j.sbspro.2014.05.300 